\title{
Incidence of Pulmonary Carcinogenic Changes After One Hundred Weeks of Solitary a-quartz Exposure in Albino Wistar Rats (In vivo Study)
}

Original Article

\author{
Ahmed S. Ahmed
}

Department of Anatomy and Embryology, College of Medicine, Tanta University. Tanta, Egyptt

\begin{abstract}
Introduction: Quartz is one of the most well-known compounds in earth crust which could be inhaled causing silicosis which is an occupational lung disease marked by pulmonary inflammation and scarring mainly in the upper lobes of the lungs. Many researchers linked between chronic repetitive quartz exposure and pulmonary histopathological changes in the form of hyperplasia and neoplastic lesions, but in our present study we aim to examine the carcinogenic effect of single exposure of quartz in two years period.

Material and Methods: 80 Albino Wistar rats were divided into four groups. Q-60 and Q-100 groups received single dose of quartz $(5 \mathrm{mg})$ by intratracheal injection and sacrificed after 60 and 100 weeks of exposure respectively. S-60 and S-100 groups received intratracheal $0.2 \mathrm{ml}$ saline injection and sacrificed after 60 and 100 weeks of exposure respectively. Lungs were collected for histopathological and immunohistochemical studies.

Results: Lung tissue of Q60 and Q100 showed inflammatory cells infiltrations, pulmonary edema and pulmonary fibrosis. Pulmonary edema and fibrosis are significantly apparent in Q60 than in Q 100. Q60 and S60 groups showed inflammatory cells infiltration but neither hyperplastic nor neoplastic changes were detected. Q100 and S100 groups showed inflammatory cells infiltration together with hyperplastic changes, adenoma, adenocarcinoma and papillomatous formation. Q100 group showed higher incidence of adenoma and adenocarcinoma if compared to S100, inflammatory cells infiltration was positively correlated with formation of hyperplastic and neoplastic changes. Examination of anti Napsin A and anti-CD-86 stained sections showed negative reaction in S60 and S100 groups while reaction in Q60 and Q100 groups was significantly strong positive.

Conclusion: Our study revealed that quartz can be detected in lung tissue after two years of this solitary exposure inducing hyperplastic and precancerous lesions which could be reflected on quartz workers health.
\end{abstract}

Received: 17 May 2020, Accepted: 16 June 2020

Key Words: Carcinogenic; napsin A; quartz; silicosis; single exposure.

Corresponding Author: Ahmed S. Ahmed, PhD, Department of Anatomy and Embryology, College of Medicine, Tanta University, Tanta, Egypt, Tel.: +20 1006615160, E-mail: Ahmedsahmed.tanta@gmail.com

ISSN: 1110-0559, Vol. 44, No.2

\section{INTRODUCTION}

Quartz (Q) is a colorless hard compound found in earth crust, classified into $\alpha$ and $\beta$ subtypes ${ }^{[1]}$. Its crystals are hexagonal in shape found twinned together ${ }^{[2]}$. It is a major constituent of granite, sandstones and quartzite ${ }^{[3]}$, extracted from open pit mines by help of explosives ${ }^{[4]}$. Cutting, grinding and chipping are the major steps to prepare the final Q products with a hazard of emission of small crystalline particles in the surrounding air that could be inhaled by the workers inducing silicosis ${ }^{[5,6]}$.

Silicosis is an occupational disease characterized by lung inflammation with multiple nodular lesions ${ }^{[7]}$. It results in fifty thousand deaths per year and considered the commonest occupational pulmonary diseases globally ${ }^{[8]}$. It is common in mining and ceramic workers ${ }^{[9]}$. The risk of quartz induced silicosis (QIS) range from 5\% up to $70 \%$ depending on a variety of factors such as age of the patient and the type of inhaled quartz which determine crystal surface characteristics $^{[10,11,12,13]}$.
Histopathologically, silicosis is characterized by formation of fibrotic nodular scars mainly around the vascular and lymphatic pathways ${ }^{[14]}$. Autopsy studies revealed that QIS is associated with pulmonary carcinoma, with positive correlation between $\mathrm{Q}$ exposure frequency and pulmonary cancer incidence. Lung pathology incidence increases if $Q$ air concentration reaches $2 \mathrm{mg} / \mathrm{m} 3^{[15,16,17,18,19,20,21]}$.

Many factors, such as particle size and area of production, determine the carcinogenic potential of $\mathrm{Q}^{[22]}$. $\mathrm{Q}$ induced pulmonary inflammation depends also on rat species which show more extensive pulmonary changes if compared to humans ${ }^{[23]}$. Previous studies reported that Q exposure induces carcinogenic effects in many experimental animals but not in albino Wistar rats. Q crystals which have approximately $5 \mu \mathrm{m}$ diameter can reach alveoli and then migrate to surrounding lymphatics releasing free oxidative radicles inducing more extensive pneumocytes injury. Type II pneumocytes may then proliferate to produce pulmonary hyperplastic changes ${ }^{[24]}$. Napsin A immunostaining could be used to distinguish between precancerous and inflammatory 
changes $^{[25]}$. Many researchers reported the association between chronic repetitive $\mathrm{Q}$ exposure and pulmonary histopathological changes but in our present study we aim to examine the carcinogenic effect of single exposure of $Q$ in two years period ${ }^{[26,27]}$.

\section{MATERIAL AND METHODS}

\section{Chemicals}

$\alpha$-quartz powder was purchased from Sigma-Aldrich Chemie, GmbH (Germany) with particles maximum and minimum diameter were 16 and $0.3 \mu \mathrm{m}$ respectively.

\section{Animals}

80 Albino Wistar rats were obtained from the animal house of Tanta University, with average weight around $100 \mathrm{gm}$ and 8 weeks average age. Animals were housed individually. Free access to chow and water was allowed. 12 light/dark cycle was kept. By the help of air conditions, the temperature was kept $25^{\circ} \mathrm{C}$ (in accordance to national and institutional guidelines). This research study was approved by Research and Ethics Committee, Quality Assurance Unit, Faculty of Medicine, Tanta University, Egypt.

\section{Experimental design}

Rats were divided into four groups $(\mathrm{n}=20)$. Q-60 group received single dose of quartz $(5 \mathrm{mg})$ in saline vehicle $(0.2 \mathrm{ml})$ by intratracheal injection and sacrificed after 60 weeks of exposure. S-60 group received single dose saline $(0.2 \mathrm{ml})$ by intratracheal injection and sacrificed after 60 weeks of exposure. Q-100 group received single dose of quartz $(5 \mathrm{mg})$ in saline vehicle $(0.2 \mathrm{ml})$ by intratracheal injection and sacrificed after 100 weeks of exposure. S-100 group received single dose saline $(0.2 \mathrm{ml})$ by intratracheal injection and sacrificed after 100 weeks of exposure. All intratracheal injections were accomplished under general anesthesia by help of MicroSprayer ${ }^{\circledR}$ Aerosolizer for Rat, Model IA-1B-R (Penn-Century, USA). After scarification, lungs were collected for histopathological and immunohistochemical studies.

\section{Histopathological examination}

Hematoxylin and eosin staining was done in accordance to $^{[28]}$. Briefly, fresh lung tissue was cut into $1 \mathrm{~cm} 3$ cubes immediately after extraction from the rats. It was placed in fixative solution (10\% paraformaldehyde) and left for 48 hours then placed in tissue processing cassettes. By help of ascending grades of alcohol, tissue was dehydrated to remove water and formalin traces from tissue then immersed in xylene to remove alcohol and facilitate paraffin wax infiltration into lung tissue. Cassettes were placed on warm plates for ten minutes then lung tissue were removed and immersed in paraffine blocks. After paraffine solidification, the blocks were cut into sections ( $5 \mu \mathrm{m}$ thick) by using manually operated rotary microtome CUT,4050F, R (Microtec Laborgeräte GMBH, Germany). Tissue sections were placed on glass microscope slides, rehydrated, stained with hematoxylin (stains nuclei in blue) for 10 minutes and eosin (stains cytoplasm in red) for 10 seconds. The stained tissue sections were dehydrated again by ascending grades of alcohol for 10 minutes than covered by coverslip. To detect quartz particles, polarized microscopy (Olympus, Japan) was used to examine the lung tissues at X1000 magnification then histopathological examinations were performed by two expert histopathologists from pathology department, Tanta University blinded to the study. Three fields per section were examined and scoring was done according to lesion severity as shown in (Table 1).

Table 1: Histopathological scoring of lung tissue according to severity of lesion

\begin{tabular}{cc}
\hline Score & Severity \\
\hline 0 & No lesion \\
1 & Mild lesion \\
2 & Moderate lesion \\
3 & Sever lesion \\
\hline
\end{tabular}

\section{Immunohistochemistry examinations}

Immunohistochemistry was done in accordance to ${ }^{[29]}$. Briefly, paraffine embedded tissue sections were sliced (5 $\mu \mathrm{m}$ thick) and mounted to charged slides. Sections were deparaffinized and rehydrated by descending grades of alcohol. Endogenous peroxidase activity was quenched by placing the tissue sections in 3\% hydrogen peroxide for 10 minutes. $200 \mu \mathrm{l}$ of diluted 1ry antibody [Anti-rat Napsin monoclonal antibody at 1:100 dilution (Abeomics Inc., USA) and anti-rat CD-86 monoclonal antibody at 1:100 dilution (Abeomics Inc., USA)] were mounted to the tissue after dilution with antibody diluent, SignalStain ${ }^{\circledR}$ diluent( (Biocompare, USA) as per manufacturer protocol. Napsin $\mathrm{A}$ is an inflammatory and hyperplasia marker, while CD-86 is a macrophage marker. Slides were incubated overnight at 4oc in a humidified chamber. In next morning, slides were washed by wash buffer for three minutes then covered with two drops of Signal Stain Boost Detection Reagent followed by incubation at room temperature in humidified chamber for 30 minutes. $200 \mu \mathrm{l}$ of SignalStain ${ }^{\circledR}$ DAB (Biocompare, USA) were applied to each section. After staining, slides were immersed in distilled water then counterstained with hematoxylin to stain nuclei in blue for better visualization. Coverslips were applied. Three fields per section were analyzed by Image J 1.24 v. software.

\section{Statistical analysis}

SPSS software, $25 \mathrm{~V}$. (SPSS Inc., USA) was used for data analysis, data were expressed in mean, plus-minus standard deviation and probability value was considered significant if $<0.05$. Tukey-Kramer test was used for groups histopathological comparison. Spearman's rank correlation coefficient was used to compare the correlations between inflammation scores and the numbers of hyperplastic and neoplastic lesions. 


\section{RESULTS}

\section{Histopathological examination}

Quartz particles were detected by polarized microscopy in Q60 and Q 100 groups as spherical particles $(\mathrm{p}=0.0001)$ (Figure 1), which suggest that quartz particles remain in the lung tissue up to 100 weeks after exposure as shown in (Table 2). Histopathological examination of the lung tissue showed that S60 and S100 groups showed normal histological architecture, while lung tissue of Q60 and Q100 showed inflammatory cells infiltrations, pulmonary edema and pulmonary fibrosis (Figure 2). Histopathological scoring (Figure 3) showed a significant $(p<0.01)$ inflammatory changes in Q60 if compared to $\mathrm{S} 60$ and in Q100 in comparison to S100. Pulmonary edema and fibrosis are significantly apparent $(p<0.01)$ in Q60 than in Q 100 which suggest that quartz induces pathological changes in lung tissue up to 100 weeks after single exposure. Q60 and S60 groups showed inflammatory cells infiltration but neither hyperplastic nor neoplastic changes were detected. Q100 and S100 groups showed inflammatory cells infiltration together with hyperplastic changes, adenoma, adenocarcinoma and papillomatous formation (Figure 3).
Q100 group showed significant $(p<0.05)$ higher incidence of adenoma and adenocarcinoma if compared to S100 (Figure 4). At Q100 group, inflammatory cells infiltration shows significant $(p<0.05)$ positively correlated with formation of hyperplastic and neoplastic changes (Figure 5) which suggest that quartz exposure is positively associated with carcinogenic changes in the lung.

\section{Immunohistochemistry examinations}

Examination of anti Napsin A stained sections showed negative reaction in $\mathrm{S} 60$ and $\mathrm{S} 100$ groups while reaction in Q60 and Q100 groups was significantly strong positive $(p<0.01)$ if compared to saline related groups. There was insignificant difference between Q60 and Q100 groups. While examination of anti-CD-86 stained sections showed negative reaction in saline related groups. Q60 and Q100 groups showed significant strong positive reaction $(p<0.01)$ if compared to saline related groups. There was insignificant difference between Q60 and Q100 groups. Quantification of immunohistochemical results were summarized in with significant difference $(p<0.01)$ if quartz related groups were compared to saline related groups (Figure 6).
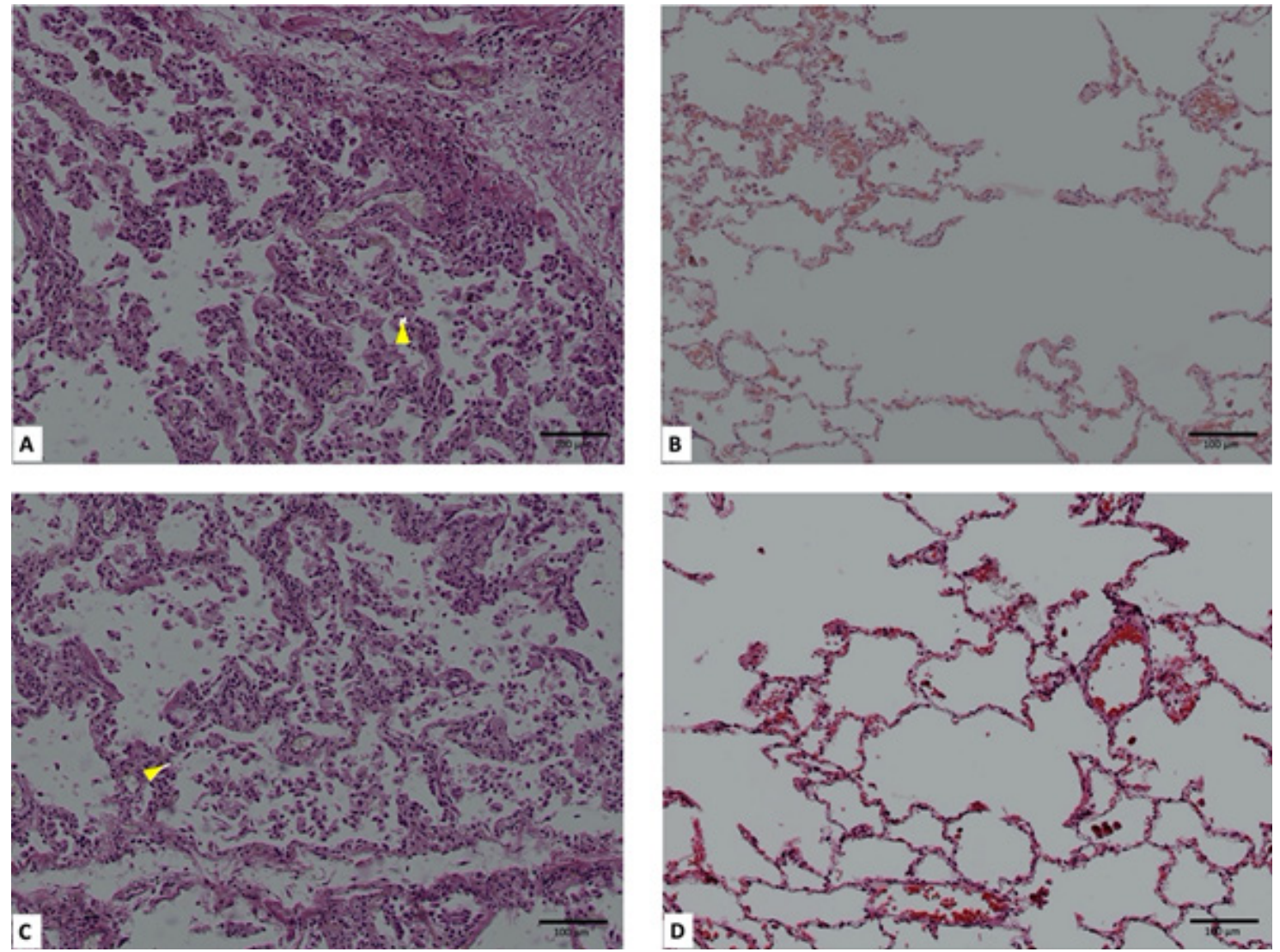

Fig. 1: Photomicrograph of lung tissue sections stained with hematoxylin and eosin and examined by polarized microscope(X1000). (A), (B), (C) and (D) represent Q60, S60, Q100 and S100 groups respectively. Quartz particles appears only in Q60 and Q100 groups (Yellow arrows). 

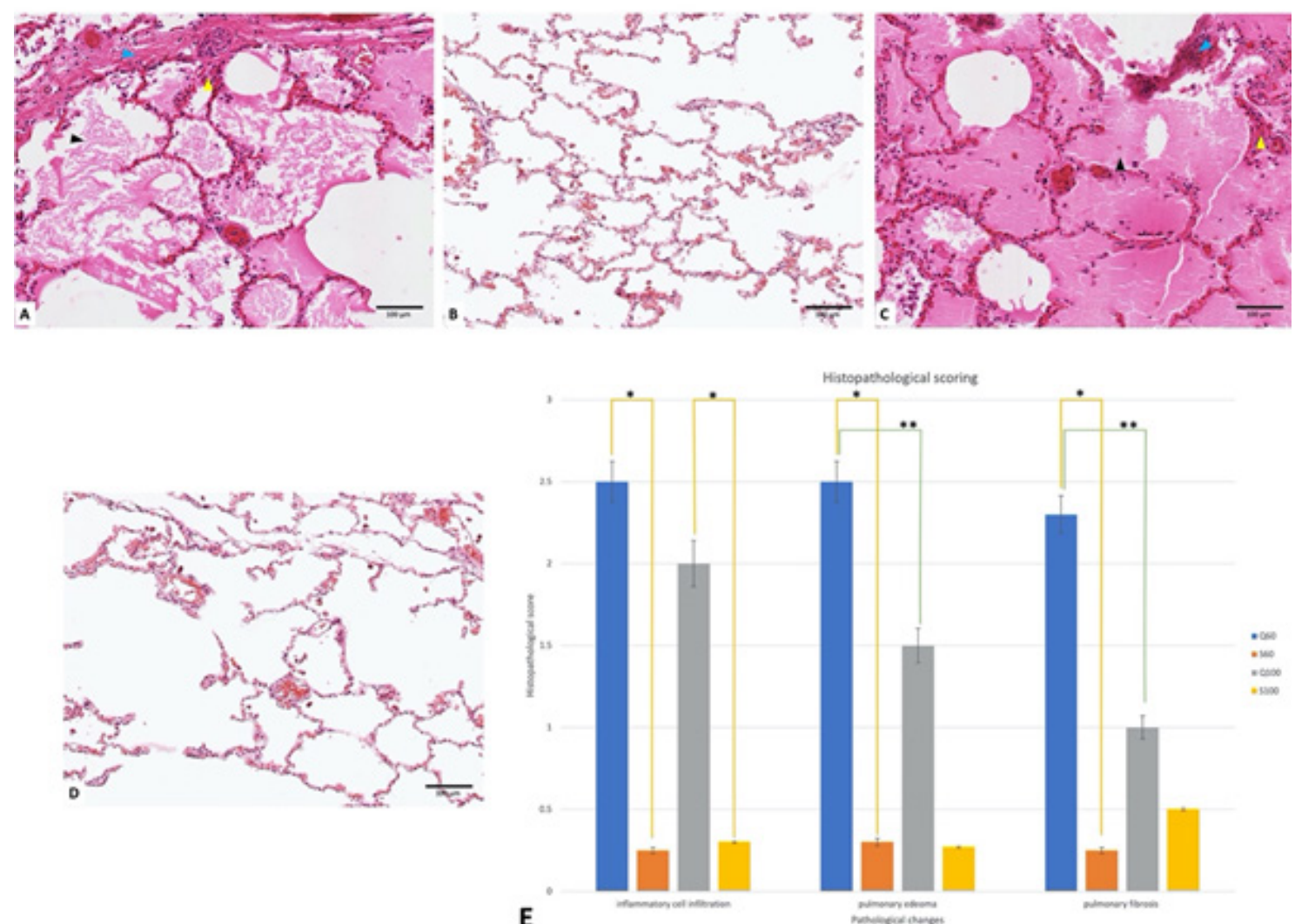

Fig. 2: Photomicrograph of lung tissue sections stained with hematoxylin and eosin (X1000) (A-D) with histopathological scoring (E). (A) Represent Q60 group with inflammatory cells infiltration (Yellow arrow), pulmonary edema (Black arrow) and pulmonary fibrosis (Blue arrow). (B) Represent S60 group with normal lung tissue which appears as spongy alveoli with normal width of their lumen lined with pneumocytes. (C) Represent Q100 group with inflammatory cells infiltration (Yellow arrow), pulmonary edema (Black arrow) and pulmonary fibrosis (Blue arrow). (D) Represent S100 group with normal lung histological architecture. (E) Represent histological scoring of the four groups. * Significant difference between quartz and saline related groups( $<0.01$ ). ** Significant difference between Q60 and Q100 groups $(p<0.01)$. Data are presented as mean \pm standard deviation.
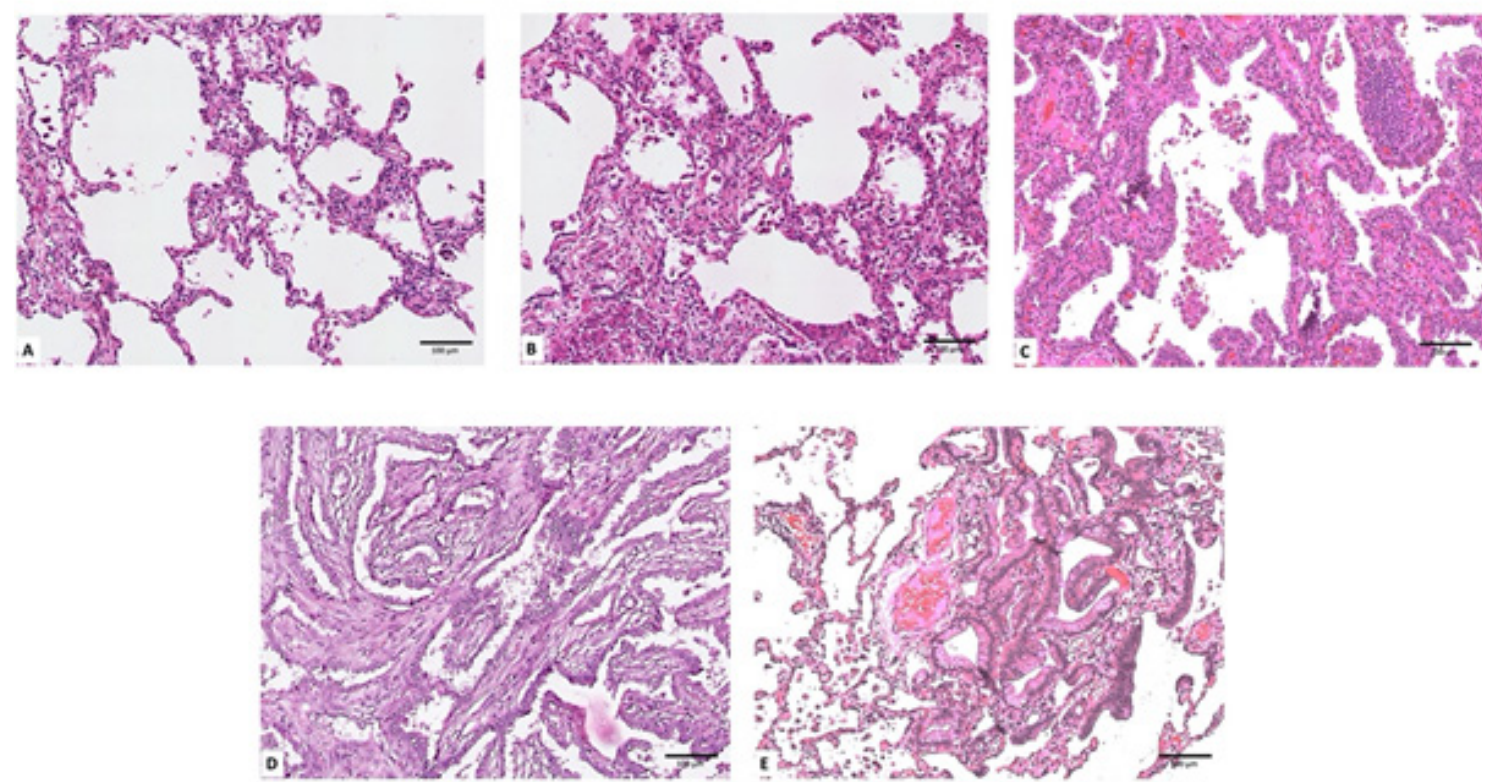

Fig. 3: Photomicrograph of lung tissue sections stained with hematoxylin and eosin (X1000) showing hyperplastic and neoplastic changes in the four groups. (A) Represent inflammatory cells infiltration in Q60 group. (B), (C), (D) and (E) represent hyperplastic changes, adenoma, adenocarcinoma and papilloma formations in Q100 group respectively. 


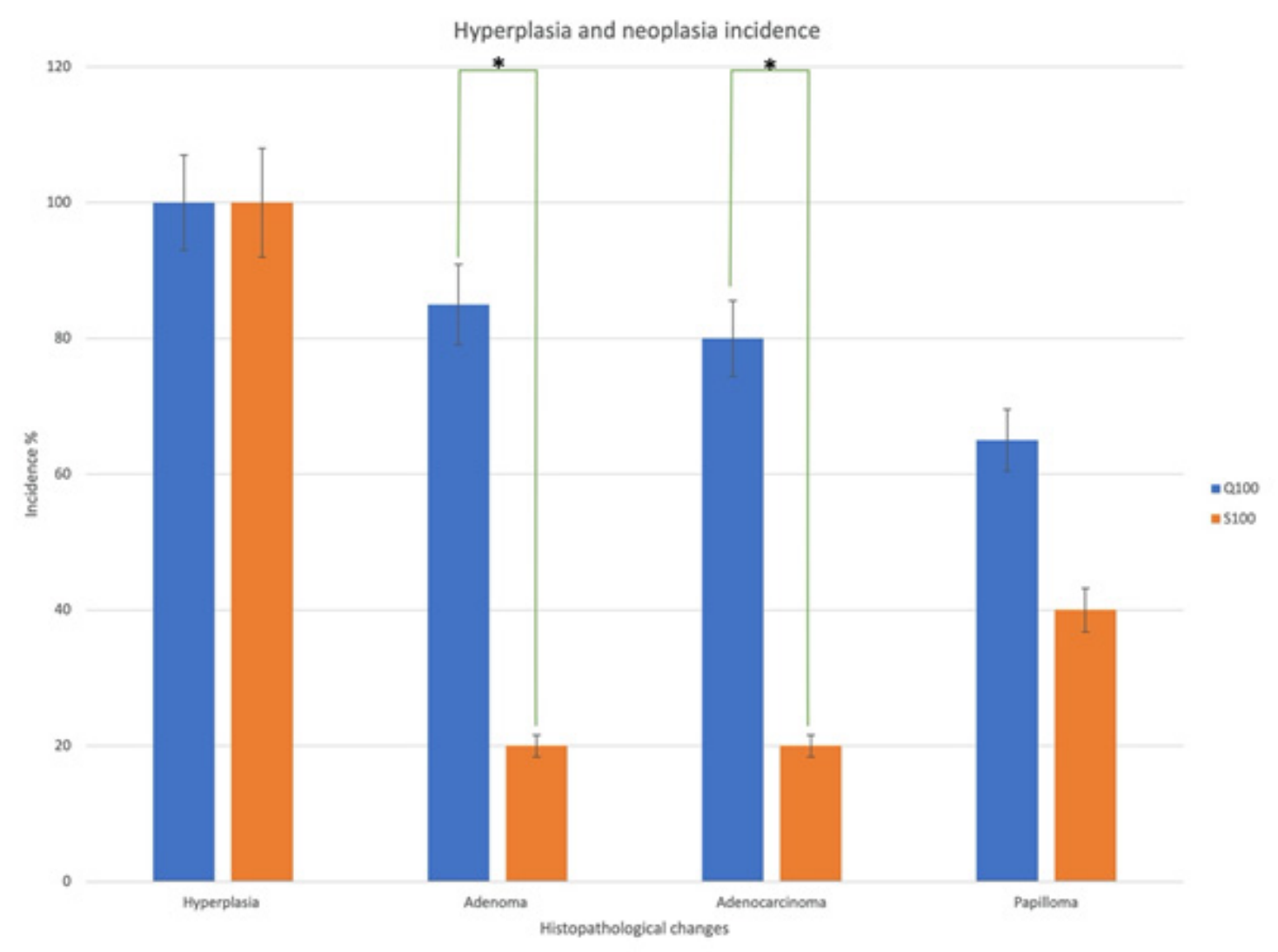

Fig. 4: Incidence of hyperplasia and neoplastic formation in lung tissue. *Significant difference between quartz and saline related groups $(p<0.05)$. Data are presented as mean \pm standard deviation.

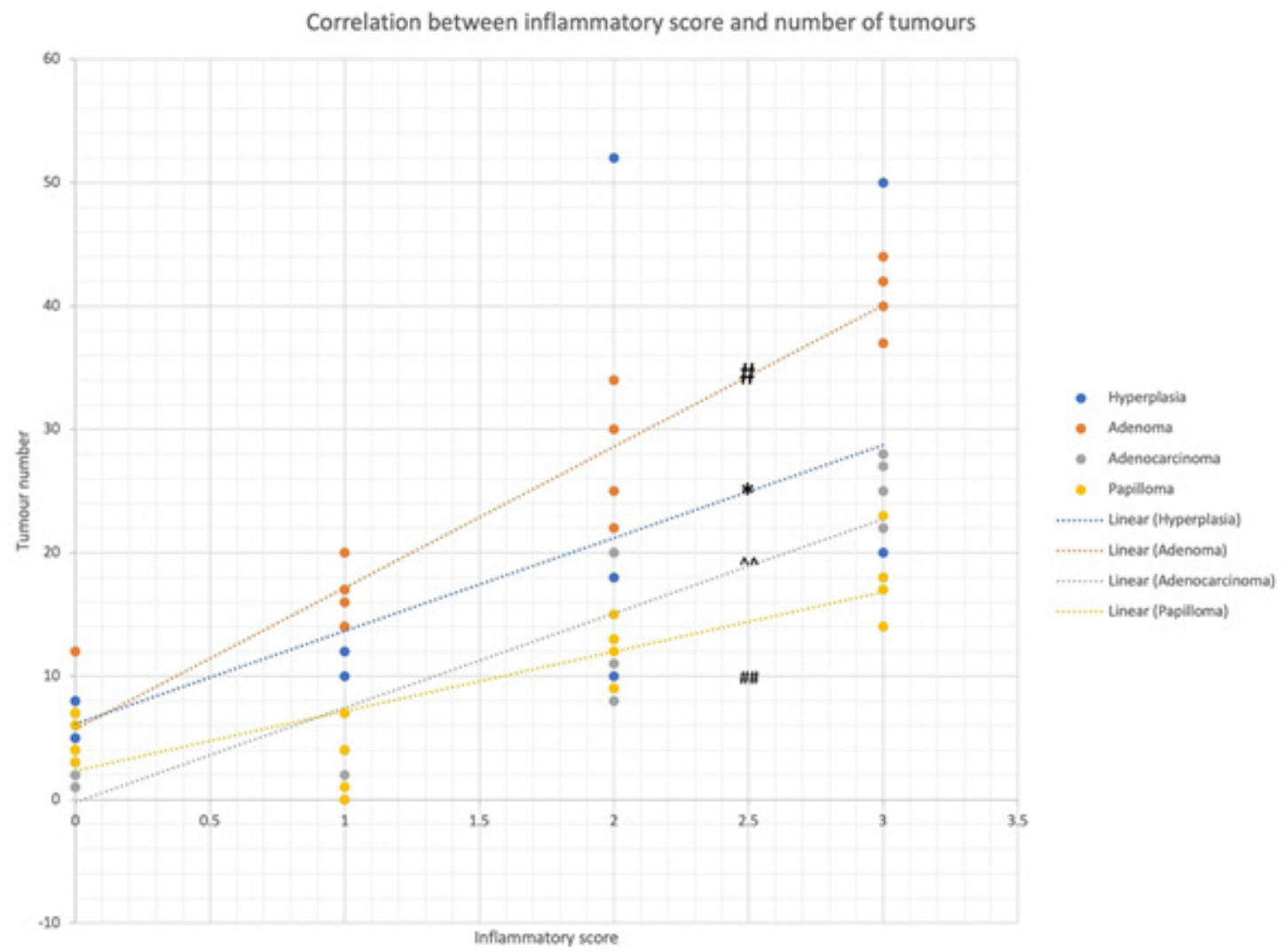

Fig. 5: Association between inflammatory score and number of hyperplastic and neoplastic changes. \# Significant association with adenoma $(p<0.01)$, * Significant association with hyperplasia $(p<0.05),{ }^{\wedge}$ Significant association with adenocarcinoma $(p<0.01)$, \#\# Significant association with papilloma $(p<0.01)$. 


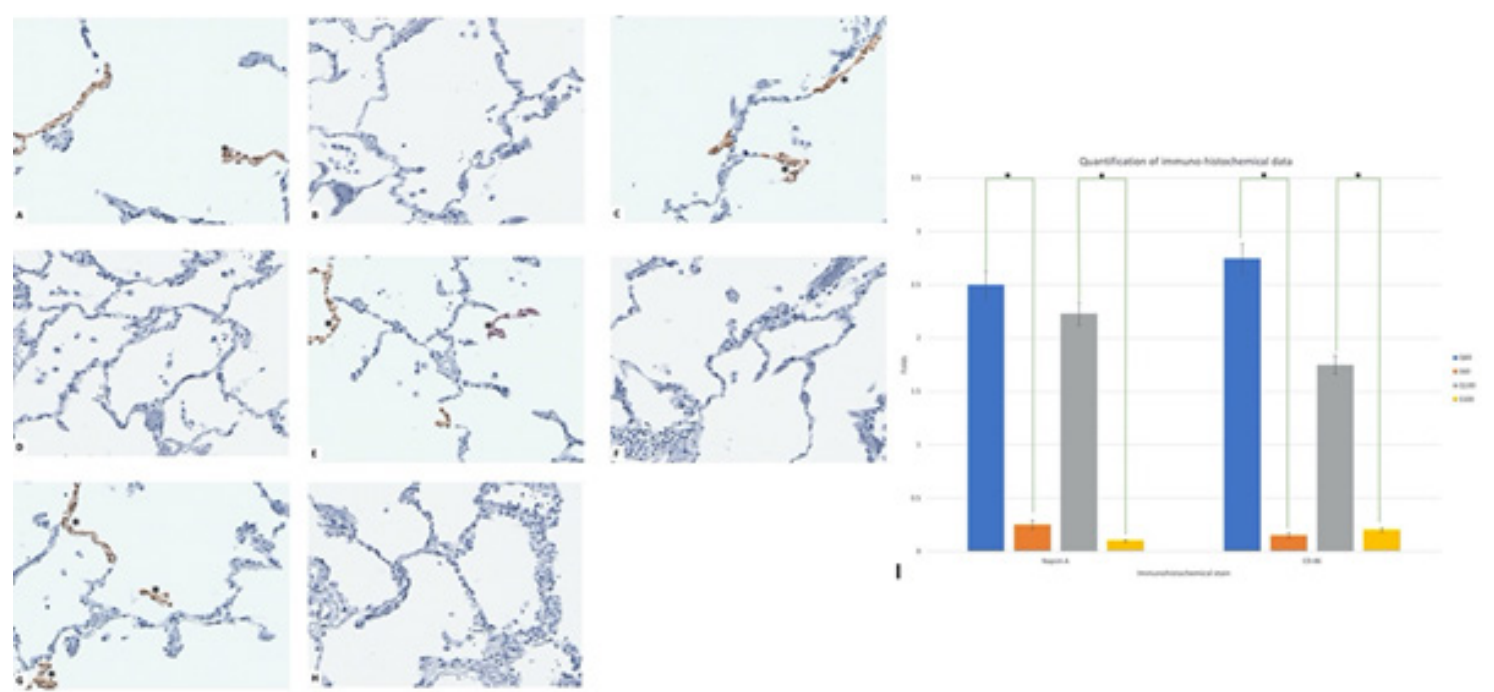

Fig. 6: Photomicrograph of lung tissue stained with Anti-rat Napsin monoclonal antibody and anti-rat CD-86 monoclonal antibody (X1000) (A-H) with quantification of immunohistochemistry results (I). (A), (B), (C) and (D) represent anti- Napsin A stained lung sections of groups Q60, S60, Q100 and S100 respectively, showed negative reaction in S60 and S100 groups while reaction in Q60 and Q100 groups was significantly strong positive if compared to saline related groups $(p<0.01)$. (E), (F), (G) and $(\mathrm{H})$ represent anti CD-86 stained lung sections of groups Q60, S60, Q100 and S100 respectively, it showed negative reaction in S60 and S100 groups while reaction in Q60 and Q100 groups was significantly strong positive ( $p<0.01)$ if compared to saline related groups. There was insignificant difference between Q60 and Q100 groups. Note, immunopositivity areas marked with (Asterisk). (I) Represent quantification of immunohistochemistry results, * significant difference $(p<0.01)$ if quartz related groups were compared to saline related groups. Data are presented as mean \pm standard deviation

Table 2: Summarization of quartz existence incidence between the four groups Q60, S60, Q100 and S100. * Denotes significant difference of Q60 and Q100 in comparison to S60 and S100 groups $(p<0.001)$

\begin{tabular}{cc}
\hline Group & Quartz existence \% \\
\hline Q60 & $100^{*}$ \\
S60 & 0 \\
Q100 & $100^{*}$ \\
S100 & 0 \\
\hline
\end{tabular}

\section{DISCUSSION}

Quartz is a natural solid component that is present in earth crust and extracted for modern industry. Workers get chronically exposed to its particles emitted in the air which constitute a dangerous hazard for their health especially the pulmonary system. In our study we examine the carcinogenic effect of a single exposure to the Q particles. In our study, Quartz particles were detected by polarized microscopy even after 100 week of the single exposure A relative short period study (duration twelve weeks) done by Albrecht et al. had revealed that quartz can be detected in lung after ninety days of Q exposure in wistar rats ${ }^{[30]}$. Last et al. reported that $Q$ could be detected in rats after one year of exposure ${ }^{[31]}$. Koga et al. reported that Q could be detected in bronchoalveolar lavage fluid sample of quartz factory workers by using polarized microscopy after three months of their employment ${ }^{[32]}$.

In the present research, lung tissue of $\mathrm{Q}$ exposed rats showed inflammatory cells infiltrations, pulmonary edema and pulmonary fibrosis. Lam et al. reported that the Q induced pulmonary edema cannot be detected within a short period of time (seven days) ${ }^{[33]}$. Martin et al. stated that volcanic ash was less toxic to lung tissue than quartz. Volcanic ash induce damage to pneumocytes I causing pulmonary edema compared to $\mathrm{Q}$ which affect pneumocytes II causing pulmonary fibrosis ${ }^{[34]}$. Chen et al. reported that, after six months of $\mathrm{Q}$ exposure the lung showed alveolar edema, thickening of interalveolar septa with inflammatory cells infiltration, while the fibrosis of lung tissue appeased after one year of the exposure with increase in the collagen content of the lung tissue ${ }^{[35]}$.

Our results showed that, histopathological scoring increased in $\mathrm{Q}$ exposed groups if compared to saline related groups. The lung pathogenesis and inflammatory response depends mainly of $\mathrm{Q}$ particle surface properties as mentioned by Albrecht et al. ${ }^{\left[{ }^{[6]}\right.}$. Kanie added that, ambroxol hydrochloride relieve Q induced lung pathological changes in F344 rats ${ }^{[37]}$. Pulmonary edema and fibrosis detected in our results are of higher significance after 60 weeks of exposure if compared to results obtained after 100 weeks of exposure which comes in agreement with Seiler et al ${ }^{[38]}$ who reported that Q associated lung tumors are time and dose dependent and caused by oxo-guanine in the nuclear DNA of lung cells.

In our study, Q60 and S60 groups showed inflammatory cells infiltration but neither hyperplastic nor neoplastic changes were detected. This comes in agreement with Gottschling et al. ${ }^{[39]}$, in his study, he examined the effect of indium phosphide on lung tissue of Fischer 344 rats, after 
3-month of exposure severe inflammatory cells infiltration was noticed [with high expression of inducible nitric oxide synthase(i-NOS) and Cyclooxygenase-2 (COX-2)] but after 2 years pulmonary adenomas and carcinomas developed [with high expression of glutathione S-transferase Pi (GST$\mathrm{Pi}$ ) and 8-hydroxydeoxyguanosine (8-OhdG)].

In the present research, after 100 weeks of $\mathrm{Q}$ exposure lung tissue showed inflammatory cells infiltration together with hyperplastic changes, adenoma, adenocarcinoma and papillomatous formation which comes in consonance with Antunes et al. ${ }^{[40]}$ who stated that inflammatory cytokines and chemokines plays an important link between inflammatory changes and neoplastic development. While, Belinsky ${ }^{[41]}$ reported the role of DNA-methyltransferase in the development of lung cancer in association with inflammatory changes. Belinsky et al ${ }^{[42]}$ reported the role of pneumocytes II in the development of lung cancers. He mentioned that hyperplasia was detected in septa between alveoli which develop into adenomas and carcinomas due to activation of K-ras gene. In our results, after 100-week of exposure, Q related groups showed higher incidence of lung adenoma and adenocarcinoma if compared to saline related groups which comes in agreement with other study in which rats were exposed to a higher dose of $\mathrm{Q}^{[43]}$. A previous study reported that the tissue inflammation induced by $\mathrm{Q}$ favor carcinogenic pathway via T-lymphocyte involvement ${ }^{[44]}$.

In the present work, At Q100 group, inflammatory cells infiltration was positively correlated with formation of hyperplastic which suggest that quartz exposure is positively associated with carcinogenic changes in the lung which may be caused by Interleukin-1beta (IL-1 $\beta$ ) activation pathway as mentioned by Hogmalm et al. ${ }^{[45]}$ or by the increased expression of SAM Pointed Domain Containing ETS Transcription Factor (SPDEF) and Forkhead Box A3 (FOXA3) as mentioned by Chen et al. ${ }^{[46]}$.

Our results showed that, inflammatory cells infiltration was positively correlated with formation of neoplastic changes. Zeng et al..$^{[4]}$ reported that tumor necrosis factor, interleukin 1 and interleukin 6 overexpression could link between lung inflammation and some precancerous lesions. In the present work, examination of anti napsin A stained sections showed strong positive reaction in both Q60 and Q100 groups which indicate carcinogenic lung hyperplasia as mentioned by Yokohira et al.$^{[48]}$. In the present work, while examination of anti-CD-86 stained sections, strong positive reaction was noticed in $\mathrm{Q}$ related groups which comes in agreement with Long et al. ${ }^{[49]}$.

\section{CONCLUSIONS}

In conclusion, our study revealed that a single intratracheal administration of quartz has a hazardous pulmonary effect even in a very diluted concentration $(5 \mathrm{mg})$ and quartz can be detected in lung tissue after two years of this solitary exposure. It can induce hyperplastic and precancerous lesion. This could be reflected on human health. Precautions should be taken to decrease the exposure of workers to quartz to avoid any health-related problems.

\section{CONFLICT OF INTERESTS}

There are no conflicts of interest.

\section{REFERENCES}

1. Kawasaki H. A review of the fate of inhaled $\alpha$-quartz in the lungs of rats. Inhal Toxicol. 31(1):25-34(2019).

2. Donaldson K, Borm PJ. The quartz hazard: a variable entity. Ann Occup Hyg. 42(5):287-294(1998).

3. López-Lilao A, Escrig A, Orts MJ, et al. Quartz dustiness: A key factor in controlling exposure to crystalline silica in the workplace. J Occup Environ Hyg. 13(11):817-828(2016).

4. Ziemann C, Escrig A, Bonvicini G, et al. OrganosilaneBased Coating of Quartz Species from the Traditional Ceramics Industry: Evidence of Hazard Reduction Using In Vitro and In Vivo Tests. Ann Work Expo Health. 61(4):468-480(2017).

5. Huang R, Yi P, Tang Y. Probing the interactions of organic molecules, nanomaterials, and microbes with solid surfaces using quartz crystal microbalances: methodology, advantages, and limitations. Environ Sci Process Impacts. 19(6):793-811(2017).

6. Kang JK, Park JA, Yi IG, et al. Experimental and modeling analyses for interactions between graphene oxide and quartz sand. J Environ Sci Health A Tox Hazard Subst Environ Eng. 52(4):368-377(2017).

7. Fernández Álvarez R, Martínez González C, Quero Martínez A, et al. Guidelines for the diagnosis and monitoring of silicosis. Arch Bronconeumol. 51(2):86-93(2015).

8. Rees D, Murray J. Silica, silicosis and tuberculosis. Int J Tuberc Lung Dis. 11(5):474-484(2007).

9. Wang W, Yu Y, Xiao J, et al. A Novel Variant of Desmoplakin Is Potentially Associated with Silicosis Risk. DNA Cell Biol. 37(11):925-931(2018).

10. Graham WG. Silicosis [published correction appears in Clin Chest Med 1992 Dec;13(4):X]. Clin Chest Med. 13(2):253-267(1992).

11. Iga N, Nishi H, Fujimoto N, et al. Clinical features of secondary spontaneous pneumothorax complicated with silicosis. Respir Investig. 56(2):144-149(2018).

12. Jindal SK. Silicosis in India: past and present. Curr Opin Pulm Med. 19(2):163-168(2013).

13. Guarnieri G, Bizzotto R, Gottardo O, et al. Multiorgan accelerated silicosis misdiagnosed as sarcoidosis in two workers exposed to quartz conglomerate dust. Occup Environ Med. 76(3):178-180(2019).

14. Ehrlich R. History and medicine--The case of silicosis. Am J Ind Med. 58 Suppl 1:S1-S2(2015).

15. Cullinan P, Reid P. Pneumoconiosis. Prim Care Respir J. 22(2):249-252(2013). 
16. Gamble JF, Hessel PA, Nicolich M. Relationship between silicosis and lung function. Scand J Work Environ Health. 30(1):5-20(2004).

17. Barmania S. Deadly denim: sandblasting-induced silicosis in the jeans industry. Lancet Respir Med. 4(7):543 (2016).

18. Rimal B, Greenberg AK, Rom WN. Basic pathogenetic mechanisms in silicosis: current understanding. Curr Opin Pulm Med. 11(2):169-173(2005).

19. Elkard I, Zaghba N, Benjelloun $\mathrm{H}$, et al. La silicotuberculose [Silicotuberculosis]. Rev Pneumol Clin. 72(3):179-183(2016).

20. Kramer MR, Blanc PD, Fireman E, et al. Artificial stone silicosis [corrected]: disease resurgence among artificial stone workers [published correction appears in Chest. 2012 Oct;142(4):1080]. Chest. 142(2):419-424(2012).

21. Yang Z, Li Q, Yao S, et al. Down-Regulation of miR-19a as a Biomarker for Early Detection of Silicosis. Anat Rec (Hoboken). 299(9):1300-1307(2016)

22. Donaldson K, Borm PJ. The quartz hazard: a variable entity. Ann Occup Hyg. 42(5):287-294(1998).

23. López-Lilao A, Escrig A, Orts MJ, et al. Quartz dustiness: A key factor in controlling exposure to crystalline silica in the workplace. J Occup Environ Hyg. 13(11):817-828(2016).

24. Ziemann C, Escrig A, Bonvicini $\mathrm{G}$, et al. Organosilane-Based Coating of Quartz Species from the Traditional Ceramics Industry: Evidence of Hazard Reduction Using In Vitro and In Vivo Tests. Ann Work Expo Health. 61(4):468-480(2017).

25. Rekhtman N, Pietanza CM, Sabari J, et al. Pulmonary large cell neuroendocrine carcinoma with adenocarcinoma-like features: napsin A expression and genomic alterations. Mod Pathol. 31(1):111-121(2018).

26. Rekhi B, Deodhar KK, Menon S, et al. Napsin A and WT 1 are useful immunohistochemical markers for differentiating clear cell carcinoma ovary from highgrade serous carcinoma. APMIS. 126(1):45-55(2018).

27. Porcel JM. Biomarkers in the diagnosis of pleural diseases: a 2018 update. Ther Adv Respir Dis. 12:1753466618808660(2018).

28. Feldman AT, Wolfe D. Tissue processing and hematoxylin and eosin staining. Methods Mol Biol. 1180:31-43(2014).

29. Ramos-Vara JA. Principles and Methods of Immunohistochemistry. Methods Mol Biol. 1641:115-128(2017).

30. Albrecht C, Höhr D, Haberzettl $\mathrm{P}$, et al. Surface-dependent quartz uptake by macrophages: potential role in pulmonary inflammation and lung clearance. Inhal Toxicol. 19 Suppl 1:39-48(2007).
31. Last JA, Reiser KM. Effects of silica on lung collagen. Ciba Found Symp. 121:180-193(1986).

32. Erren TC, Morfeld P, Glende CB, et al. Meta-analyses of published epidemiological studies, 1979-2006, point to open causal questions in silica-silicosis-lung cancer research. Med Lav. 102(4):321-335(2011).

33. Lam CW, James JT, McCluskey R, et al. Pulmonary toxicity of simulated lunar and Martian dusts in mice: I. Histopathology 7 and 90 days after intratracheal instillation. Inhal Toxicol. 14(9):901-916(2002).

34. Martin TR, Chi EY, Covert DS, et al. Comparative effects of inhaled volcanic ash and quartz in rats. Am Rev Respir Dis. 128(1):144-152(1983).

35. Chen J, Wang X, Lou J, et al. Relationship of jute dust to interstitial fibrosis in rat lung. Arch Environ Health. 58(3):151-155(2003).

36. Albrecht C, Höhr D, Haberzettl $\mathrm{P}$, et al. Surface-dependent quartz uptake by macrophages: potential role in pulmonary inflammation and lung clearance. Inhal Toxicol. 19 Suppl 1:39-48(2007).

37. Kanie S, Yokohira M, Yamakawa K, et al. Suppressive effects of the expectorant drug ambroxol hydrochloride on quartz-induced lung inflammation in F344 rats J Toxicol Pathol. 30(2):153-159(2017).

38. Seiler F, Rehn B, Rehn S, et al. Quartz exposure of the rat lung leads to a linear dose response in inflammation but not in oxidative DNA damage and mutagenicity. Am J Respir Cell Mol Biol. 24(4):492-498(2001).

39. Gottschling BC, Maronpot RR, Hailey JR, et al. The role of oxidative stress in indium phosphide-induced lung carcinogenesis in rats. Toxicol Sci. 64(1):28-40(2001).

40. Antunes DM, Rodrigues MFSD, Guimarães DM, et al. Nonsteroidal Anti-inflammatory Drugs Modulate Gene Expression of Inflammatory Mediators in Oral Squamous Cell Carcinoma. Anticancer Res. 39(5):2385-2394(2019).

41. Belinsky SA. Role of the cytosine DNA-methyltransferase and p16INK4a genes in the development of mouse lung tumors. Exp Lung Res. 24(4):463-479(1998).

42. Belinsky SA, Devereux TR, Foley JF, et al. Role of the alveolar type II cell in the development and progression of pulmonary tumors induced by 4-(methylnitrosamino)1-(3-pyridyl)-1-butanone in the A/J mouse. Cancer Res. 52(11):3164-3173(1992).

43. Groth, D., Stettler, L., Platek, S., et al. Lung tumors in rats treated with quartz by intratracheal instillation in Silica, silicosis, and cancer: controversy in occupational medicine (eds. Goldsmith, D. F., Winn, D. M. \& Shy, C. M.) 243-253 (1986) 
44. Freire J, Ajona D, de Biurrun G, et al. Silica-induced chronic inflammation promotes lung carcinogenesis in the context of an immunosuppressive microenvironment. Neoplasia. 15(8):913-924(2013).

45. Hogmalm A, Bry M, Bry K. Pulmonary IL- $1 \beta$ expression in early life causes permanent changes in lung structure and function in adulthood. Am J Physiol Lung Cell Mol Physiol. 314(6):L936-L945(2018).

46. Chen $\mathrm{G}$, Korfhagen TR, Xu Y, et al. SPDEF is required for mouse pulmonary goblet cell differentiation and regulates a network of genes associated with mucus production. J Clin Invest. 119(10):2914-2924(2009).
47. Zeng S, Yang Y, Tan Y, et al. ERBB2-induced inflammation in lung carcinogenesis. Mol Biol Rep. 39(8):7911-7917(2012).

48. Yokohira M, Nakano-Narusawa Y, Yamakawa K, et al. Validating the use of napsin $\mathrm{A}$ as a marker for identifying tumorigenic potential of lung bronchiolo-alveolar hyperplasia in rodents. Exp Toxicol Pathol. 69(8):637-642(2017).

49. Long X, Song WD, Liu YY, et al. The association of non-specific chronic inflammation with dendritic cells in a rat model of chronic obstructive pulmonary disease. 34(8):609-613(2011). 
الملخص العربى

حدوث التغيرات المسببة للسرطان الرئوي بعد مئة أسبوع من التعرض الانفرادي لكوارتز ألفا في جرذان ويستار ألبينو (دراسة في الجسم الحي)

قسم التشريح والأجنة ـ كلية الطب - جامعة طنطا ـ طنطا - جمهوريه مصر العربية

مقدمة: الكوارتز هو أحد أكثر المركبات المعروفة في القترة الأرضية والتي يمكن استنشاقها مسبية السُحار السيليسي و هو مرض رئوي مهني يتميز بالتهاب رئوي وتندب بشكل رئيسي في الفصوص العلوية من الرئتين. ربط العديد من فئن

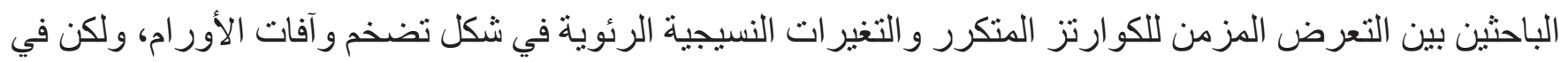
در استنا الحالية نهدف إلى فحص التأثثر السرطاني للتعرض الترنز الفردي للكو ارتز في فترة سنتين.

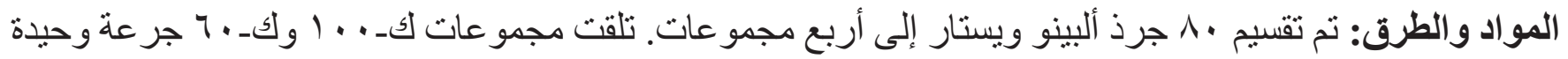

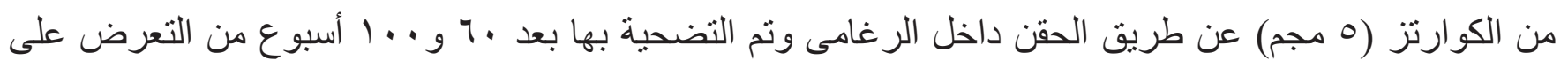
التو الي.

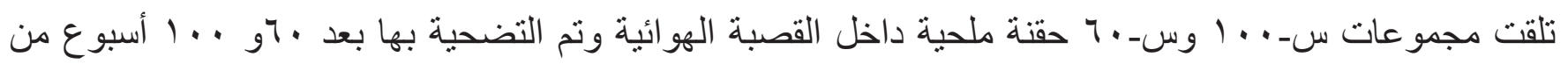
التعرض على التو الي. تم جمع الرئتين من أجل الدر اسات النسيجية المرضية ولت الكيميائية المناعية.

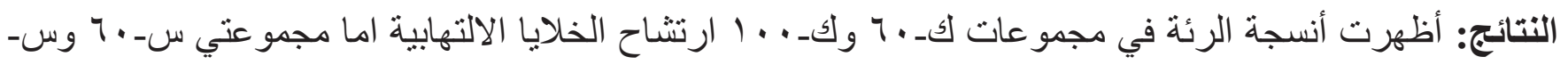

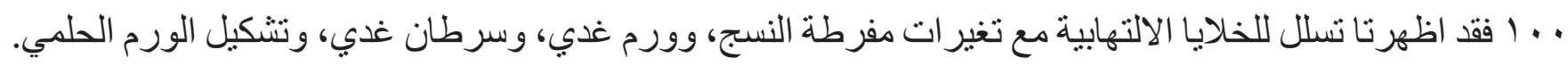

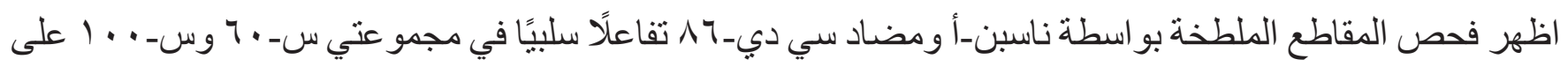
الرغم من إيجابية في المجمو عتين الأخيرتين.

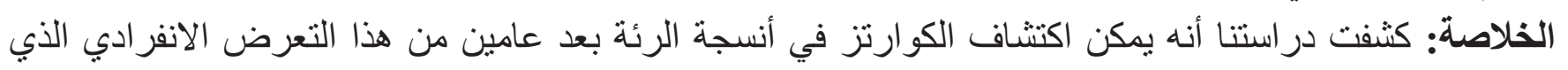

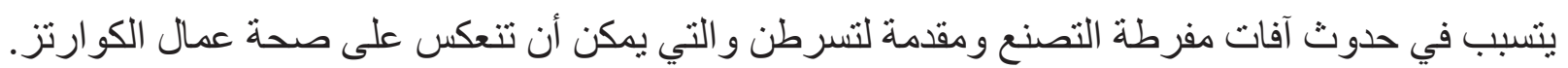

